\title{
The Effects of Managers' Business Ethics Applications on Employees' Job Satisfaction: A Study on Hotels in Turkey
}

\author{
Associate Prof. Dr. Evren GÜÇER (Corresponding Author) \\ Faculty of Tourism, Gazi University, 06380 Gölbaşı-Ankara, Turkey \\ Tel: 90-312-4851460Ｅ-mail: evrengucer@gazi.edu.tr
}

\begin{abstract}
Associate Prof. Dr. Elbeyi PELİT
Faculty of Tourism, Afyon Kocatepe University

Ahmet Necdet Sezer Kampüsü 5. Eğitim Binası, 03200 Afyonkarahisar, Turkey

Tel: 90-312-2281306Ｅ-mail: elbeyipelit@aku.edu.tr

Şerif Ahmet DEMIRDAĞ (PhD. Student)

Institute of Social Sciences, Gazi University, 06380 Gölbaşı-Ankara, Turkey

Tel: 90-312-4851460Ｅ-mail: demirdagserifahmet@gmail.com
\end{abstract}

Assist. Prof. Dr. Yalçın ARSLANTURK

Faculty of Tourism, Gazi University, 06380 Gölbaş1-Ankara, Turkey

Tel: 90-312-4851460Ｅ-mail: arslanturk2002@yahoo.com

Received: May 29, 2016 Accepted: June 15, 2016 Published: June xx, 2016

doi:10.5296/bms.v7i1.9527 URL: http://dx.doi.org/10.5296/bms.v7i1.9527 


\section{Abstract}

Thus far, much research on ethical aspects of different areas (business, marketing, medicine, managing and etc.) is made and various models are introduced in accordance with these researches. Each of these introduced models studies matters carrying ethical importance related to various areas. These researches in the aspect of establishments focus on whether the establishment applications are generally suitable to ethical standards or testing ethical appropriateness of manager behaviours. However, this research aims to introduce at which level the job satisfaction of employees, which are effected by factors such as physical conditions, payment types, social and safety opportunities and management types, are affected by the applications of managers in the extent of job ethics. In this context in the analysis related to data obtained from questionnaire studies on 813 employees working in city and resort hotel establishments, it is concluded that both job satisfaction and appropriateness of manager behaviours to ethical principles of employees working in city hotel establishments are more positive than resort hotel establishments. Besides, it is introduced by correlation and regression analysis that compliance of manager behaviours with ethical principles affects the job satisfaction level of employees drastically.

Keywords: Ethics, Ethical responsibilities, Job satisfaction, Hotel employees 


\section{Introduction}

Despite the differences in the managerial styles by the type and the capacity of the establishments, the main element of management focuses on the human factor (Budak, 1998: 60). This is more observable in service sectors, which is dominantly based upon the human labour. In tourism sector, at the very base of the optimum efficiency are the way employees perform their tasks and working conditions. In other words, businesses that fail to satisfy their employees cannot be expected to reach the maximum efficiency in the long run. The quality of the service delivered is proportional to the extent the expectations of employees are met. This is reflected in the behaviour of the employees in positive or negative manner. Thus, to prepare the conditions necessary for the employees to perform the tasks and to develop personnel policies in line with the expectations of them are indispensible implementations on the way to success. Besides, adopting and implementing principals' business ethics have gradually gained importance in the fierce competitive business settings, in sustaining their existence in the business cycles and establishing the institutional trust. Especially, those employed in managerial charges have a critical impact in adopting the ethical behaviours within the organizations. However, employees filter the decisions of the managers through their own perception format. If the decision is of ethical qualities in the minds of employees, they will exert more ambitious performance on the task they will perform. This, in fact, will lead to the positive perception of the concept of job satisfaction through the eye of employees.

\subsection{The Aim and Importance of the Research}

Nowadays, all businesses regardless of the scope are faced with many ethical problems due to the variety of activities they fulfil. Especially, such problems as oppressive sale or price differentiations, misleading advertising, incentives offered to employees or environment are some of the problems encountered in ethical terms. Considering the labour-intensive nature of service oriented establishments, the fact that the unethical practices compared to other production oriented businesses are more is a well-established view (Altuğ \& Güler, 2003). In this context, the main focus of this study is the relation between the ethical practices of hotel managers and the satisfaction of employees. To serve this purpose, the main hypothesis of this study is that the ethically compatible behaviour of mangers towards employees positively affects the satisfaction level of employees.

In this way, this study will contribute to the awareness of the ethical behaviour of employees and the prospective effects on the satisfaction level and from the managers' side will enable managers to take these effects as a result of ethical practices in the eye of employees into consideration.

\subsection{Research Questions}

Apart from the main hypothesis postulated, the answers to the following questions will be sought after; 
1- To what extent are the behaviours of the hotel managers towards the employees compatible with Professional ethics in the eye of the employees?

\section{2- What is the satisfaction level of hotel employees?}

3- Do the satisfaction levels of employees and the opinions of employees in terms of professional ethical practices differ in terms of the location of hotels (city-resort)?

4- What is the level of effect of the behaviour of managers with respect to ethical practices on the satisfaction level of employees?

\section{Literature Review}

This part of the study deals with the concepts of ethics in general, business ethics and job satisfaction. Besides, there is special emphasis on ethical behaviour and job satisfaction at hotel businesses.

\subsection{Concepts and Importance of Ethics and Business Ethics}

As a whole, the concept of ethic is the study of right and wrong conduct within a defined environment (Hatcher, 2004: 358). According to another definition, ethics is the set of values or moral principles regulating an individual's or a profession's conduct (K1rel, 2000: 3). Defining ethics as the expression of the good and bad criteria ranging from the past to the present time, Lamberton and Minor (1995: 409) hold that above all, the concept of ethics should be evaluated in order to get a good comprehension of the concept. Although there is no full-matching consensus on the content of the concept of ethics, the common point of the definition made is that it covers the criteria of what is good and bad (Aydin, 2002: 6). Business ethics is defined as the adaptation and applied norms of ethics in business settings (Frederick et. al., 1988: 52). McNamara (2004: 4) defines business ethics as the set of principles based upon doing the right thing with the awareness of right and wrong in business environment. In a similar manner Ferrel and Fraedrich (1991) hold that business ethic should focus on the moral principles and standards guiding the conduct in the world of business.

Companies are an integral part of the study we live in and hence have some responsibilities in ethical aspects (Klein \& Dawar, 2004: 205). Despite the hardships in the evaluation of what is ethical or not by the establishments, there are some models serving specifically to show what is ethical or not in the management literature (Tsalikis \& Fritzsche, 1989: 699). The models commonly employed in the related literature are Bartel Model" "Cavanagh Model" "Bornmer Model" Etzioni’s "Moderate Deontological Model", "Proden Model", "Stassen Model" and Kohlerg's "Cognitive Model Development Model" (Ural \& Yükselen, 2003: 47-55). These models perform significant functions in terms of guiding the way to the ethical principles for the establishments and managers.

Human factor is regarded as utmost importance to gain a competitive edge in the business cycles and hence within the framework modern management concept the job satisfaction of employees is one of the managerial responsibilities of the establishments. In this point, it is 
necessary that managers should be knowledgeable about the ethical responsibilities and should exert ethic-compatible behaviours in order to steer the employees for organizational objectives. On the other hand, based on the studies conducted on the issue, despite the abundance of the studies into ethical behaviours, the literature on the effect of the ethical behaviours on the employees is scant. Şimşek (1999: 69-86) lists the ethical responsibilities of managers towards employees as the responsibility for " respect for right to labour, fair pay, freedom of speech in the work place, respect to private life, safety and health conditions and enhancing the quality of life, non-discriminating behaviour among the employees and measure taken against sexual harassment, participation in the decision-making process". In a similar manner, in a study into the social responsibilities and ethical practices at establishments by İşseveroğlu (2001: 61-62), the responsibilities are listed as the followings; "fair pay, setting up unions to protect the interests of employees, right to take part in union-related activities, enabling a safe and health work conditions and avoiding exposure to religious, racial, and sexist discrimination."

The managerial approach is one of the factors thought to be influential on the perspectives of employees towards their job and work place in a general sense. This could be related to the satisfaction with their jobs. In the literature, in studies performed by such authors as (Vitell \& Davis, 1990; Boyer \& Webb, 1992; Weeks \& Nantel, 1992; Schwepker, 2001 etc.), the common conclusion is that the ethical codes in the work place or the employees' positive perception of ethical atmosphere positively affect the level of job satisfaction and organizational commitment.

In Turkey, likewise, in a study by Zehir et al. (2003), there is a positive relation between job satisfaction and organizational commitment in terms of the ethical atmosphere of the work place as perceived by employees. It is a fact that there is a need for studies with a specific focus on the probable effect of ethical practices conducted by establishments on the employees. Within this scope, this study sets out to examine the effect of ethical practices by managers on job satisfaction; therefore, it is deemed necessary to dwell on the constructs influential on job satisfaction and the place of ethical practices in these constructs.

\subsection{Job Satisfaction and the Factors Affecting Job Satisfaction}

One of the reasons why job satisfaction has become a subject of focus by not only academicians but managers as well is to sustained effort to obtain high efficiency, as held by Pfeffer (1984). Job satisfaction is assessed within the aggregate attitude towards to a variety of aspects of the works of employees (Eren, 1998: 178). In this regard, job satisfaction is defined as the situations deriving from the positive and joyous emotions of a work or work related experience (Locke, 1976: 1300; Locke, 1991: 97; Clark, 1996: 190), rational and emotional reactions to a work (Greenberg \& Baron, 1995: 169), or the results of evaluations related to a job (Scandura \& Lankau, 1997: 379). Dacis (1984) suggest that job satisfaction is the aggregation of content and discontent. Similarly, Spector (1997) defines job satisfaction as the level to express the extent of pleasure from a job. Another definition suggests that job satisfaction is a concept that states the level of content of individual stemming from job and 
the extent of significance and satisfaction with a job (Shamir \& Salomon, 1985: 455). In other words, while there is job satisfaction in the event that the expected material and immaterial rewards are at the same level, there is no job satisfaction in the event that the resulting situation falls short of expectations (Erdil et al., 2004: 18).

In the related literature, one of the most important theories developed as to job satisfaction is that of Frederick Herzberg's. According to this theory there are two dimensions of job satisfaction. These two different dimensions are motivation and hygiene factors. According to Herzberg hygiene factors do not lead to job satisfaction but prevent job dissatisfaction. Motivating factors, although not directly affecting job satisfaction, have a relation with job satisfaction in an indirect manner (İncir, 1990: 10). Hygiene factors could be exemplified as management, working conditions, and pay and co-worker relations. For example, pay rises do not directly lead to satisfaction but prevents it from occurring. On the other hand, motivation factors could be thought of as achievement, recognition, the nature of the job, responsibility and promotion (Lu et. al., 2005; Togia et. al., 2004; Tütüncü, 2000; Tütüncü \& Çiçek, 2000; Akoğlan \& Kozak, 1995).

Cherrington (1994: 287) emphasized the nature of the job factors as one of the most important variables affecting job satisfaction and highlighted the structural characteristics of the job, achievement and opportunity to be recognized, material and immaterial rewards and pay as the important factors. Similarly, some researchers point some fundamental elements determining job satisfaction or dissatisfaction, such as pay, work group, managerial style, job security, the job itself, and monitoring and work conditions (Baysal \& Tekarslan, 1996: 279; Erdoğan, 1999: 231-236; Yüksel, 2003: 216). Spector (1997), on the other hand, states such job characteristics improving the job satisfaction as requirement of differing abilities, taking up the complete responsibility of the job, the effect of the job on other people, decision making process by employees and feedback about the job performance.

There are different approaches towards job satisfaction in the literature and the classifications of job satisfaction are the ones in terms of individual and organizational characters (Blegen, 1993: 37; Özgen et. al., 2002: 329; Akınc1, 2002: 4; Bakan \& Büyükbeşe, 2004: 1-30). In these approaches, among the individual ones such as genetic or heritage properties, family, education, values, employment experience, social status and environment, duration of employment, gender, marital status, etc. are taken into account in terms of satisfaction and dissatisfaction, as for the organizational ones, there are such factors as social facilities and physical conditions, pay, the nature of the job, work discipline, in-service training, participation in decisions, delegating, rewarding, interpersonal relations, managerial styles, promotion etc. The Figure 1 details the relations among the factors and probable outcomes.

In the labour-intensive tourism sector, human factor is of great significance in terms of profitability. Hotel establishments reach their missions and objectives through employees with a trust to the organization and with high level of satisfaction (Güçer \& Demirdağ, 2014: 12). That is to say, on the basis of operating with high efficiency rate lies how employees work and work related conditions. Hotels with employees dissatisfied with their work are 
unlikely to get to the efficiency desired in the long run. For, the extent the expectations of employees are met is commensurate with the quality of the service delivered. The more the expectations are met, the higher will be the service quality to be delivered. With reference to job satisfaction, the theories developed usually seek answer to "what makes individual happy in their jobs?"

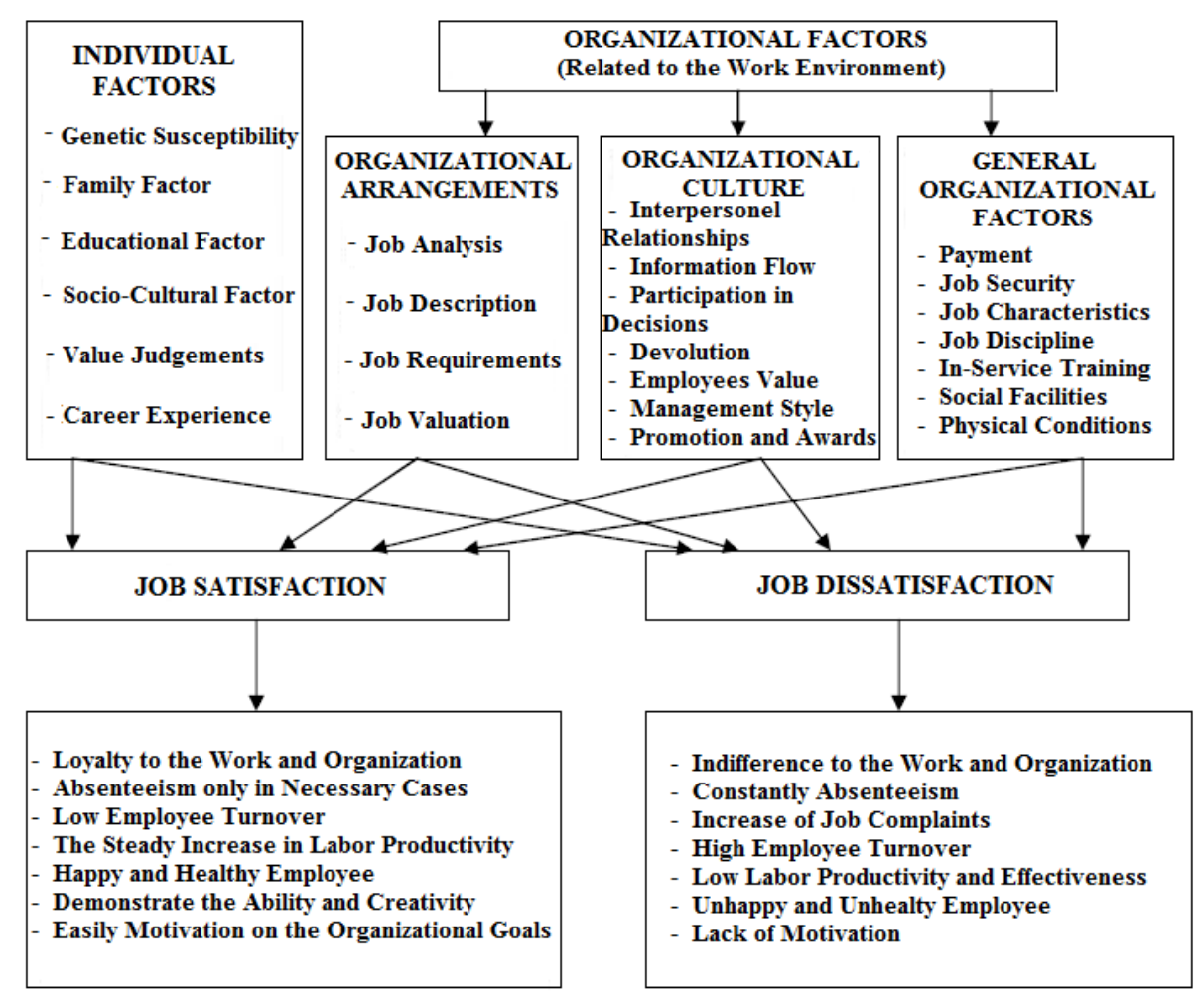

Figure 1. The Cause - Effect Relationship in Job Satisfaction (Akınc1, 2002: 6).

In the studies on job satisfaction (Curran \& Stanworth, 1981; Staw \& Ross, 1985; Staw et al., 1986; Arvey et al. 1989; Davis-Blake \& Pfeffer, 1989; İncir, 1990; House et al., 1996; Erez, 1994; Weiss \& Cropanzano, 1996; Brief, 1998; Motowidlo, 1996; Oshagbemi, 2000a; Oshagbemi, 2000b; Lam et al., 2001; Çarıçı1, 2001; Ilies \& Judge, 2002; Judge \& Bono, 2001; Griffin, 2001; Tepeci \& Bartlett, 2002; Judge et. al., 2002; İnce, 2003; Sarker et al., 2003; Lam et al., 2003; Uçkun et al., 2004; Olguntürk, 2005; Kuşluvan \& Kuşluvan, 2005; Erel, 2005; Lu et al., 2005; Lämsä \& Pučètaitè, 2006; Schoorman et al., 2007; Bozkurt \& Bozkurt, 2008; Kanbay, 2010; Arıkan, 2011; Zarvandi \& Zarvandi, 2012 etc.), there are some individual and organizational factors as well as ethical ones within the scope. However, the degree of effect of these factors on job satisfaction is not studies in a detailed manner. In this respects, this paper is thought to offer some contributions in terms of the effect of these factors on job satisfaction.

\subsection{The Importance of Business Ethics and Job Satisfaction in Hotels}

Studying work behaviour of employees as well as job satisfaction has been a topic of many 
fields ranging from management to organizational behaviour. The personality characteristics and attitude towards customers are of great significance in service delivery and all these are emotional based and therefore job satisfaction has an indispensible place in the factors mentioned above (Tarlan \& Tütüncü, 2001: 146). In this scope, the labour-intensive nature of service sector is an important determinant in quality of services delivered and thus the attitudes of employees is a point of focus that requires measurement in order to offer high-quality services and detect the lacking points in service delivery (Kantarc1, 1997: 5). Besides, problems (discontinuance to work, high turnover rate, reluctance, malfunctions in service delivery, etc.) that could be derived from job dissatisfaction (Oral, 1994: 169) make it necessary that the required conditions should be provided in order to achieve managerial objectives.

In a study by Kuşluvan and Kuşluvan (2005), it has been found out there are many individual and organizational factors affecting job satisfaction. In the study, such factors as "age, gender, marital status, education, job status, duration of employment, post, the position of the company, the content of the job, opportunities to sharpen skills, the routine of the job, pay, promotional opportunities, managerial style, relations with co-workers, benefits, job security, physical conditions, shifts, family-work life, organizational support, organizational culture, role descriptions, job orientation, employee empowerment, personnel shortage or lack-of-qualification, expectations, job-employee congruence, lack of materials" have been underlined. In addition to these factors, authors point that there have been no study into the degree of effect of the variables mentioned on job satisfaction. Within this frame, the main focus of this study is to examine the effect of the behaviours of managers on job satisfaction with specific reference to work ethics, thought to be influential on job satisfaction. Considering the service-intensive nature of tourism establishments, it is possible to mention a strong relation between ethics and the managerial process of the establishments under consideration. Apart from the need for accommodation and food and beverage, there are social needs as well, which makes this relation even stronger.

High-intensive interaction with customer and the employees during the service delivery nearly under the same operational unit, hotels, is a sign that hotels are places where social and economic relations are experienced. Besides, the possibility that customers and employees have different cultural background may lead to diverse ethical expectations and standards (Kılınç, 2000: 4). In tourism establishments, an important element of the application of ethical codes and acceptance of these codes by employees is the declaration and implementation of these codes by managers (Stevens \& Fleckenstein, 1999: 69). However studies conducted into this issued report that managers in accommodation industry do not take the ethical aspect in solutions of the problems into consideration because of the thought of "business is business" and the lack of having the instruments to define what is ethical (Whitney, 1990). Another study finds out that hotels do not have established written ethical codes and standards haven't been well understood clearly by the employees (Jazsay, 2002). In another study done by Kwansa and Farrar (1992) observed that while there are efforts focusing on training and ethical codes with their implementation, when it comes to service 
sector, ethical training and awareness are not a matter of importance.

The leading international organization in the field of tourism, United Nations World Tourism Organization has established some ethical codes in a binding nature (WTO, 2016); however, ethical issues might usually be underestimated during the decision making processes. In many of the studies into ethical issues in tourism sector (Whitney, 1990; Stevens, 1997; Fox, 2000; Kılınç, 2000; Reynolds, 2000; Yüksel \& Tunç, 2001; Sökmen \& Boylu, 2001; Kozak \& Karakaş, 2002; Tarakçıoğlu, 2003; Ünlüönen \& Olcay, 2003; Yazıcıŏlu \& Boylu, 2003; Sökmen \& Tarakçıŏlu, 2004; Ergün, 2005; Sarışık et al., 2006; Pelit \& Güçer, 2007; Huimin \& Ryan, 2011; Kim \& Brymer, 2011; Yeh, 2012 etc.), the leading ethical issues that managers are unable to meet are listed as gender discrimination, unfair promotion, interference with private life, discrediting behaviours, no support for union-related procedures, problems in providing fringe benefits, lack of safe and healthy conditions, disclosing commercial secrets, lack of fair pay and reward system, lack of performance towards creating work life quality and sexual harassment. The studies under consideration examined the managerial practices in terms of ethics and none of the above-mentioned studies directly investigated the effect of ethical practices on employees, which brings what this study aims to the forth.

\section{Methodology}

The methodology employed in a study refers to the appropriate scientific methods in order to achieve the set objectives of the study. Besides, it features some vital phases to be followed to have a scientific quality starting from literature review to finalising the report (Davis \& Cosenza, 1998: 150-151; Altunışık et al., 2004: 24-35). In line with this, the following stages have been followed to enable the desired reliability and achieve the purpose of the study.

\subsection{Data Collection Method}

An elaborative literature review on ethics, Professional ethics and factors affecting job satisfaction has been carried out. Data have been collected through questionnaires in order to examine of the hypothesis of the study that ethical behaviours of managers affect job satisfaction in a positive manner. The questionnaire is made up of three parts to determine demographic features of participants, the perception level of the employees on the ethical behaviours of managers and job satisfaction. The content of the questionnaire forms are as the following:

In the study, previous studies (Kılınç, 2000; Yüksel \& Tunç, 2001; Sökmen \& Boylu, 2001; Kozak \& Karakaş, 2002; Tarakçığlu, 2003; Ünlüönen \& Olcay, 2003; Yazıcıoğlu \& Boylu, 2003; Sökmen \& Tarakçıoğlu, 2004; Ergün, 2005; Sarışık et. al., 2006; Pelit \& Güçer, 2007) were reviewed and taken into consideration in forming the statements of questionnaire used to collect the data from employees about the behaviours of managers to employees. The questionnaire is comprised of 18 statements. The statements in the questionnaire were designed in the manner that includes the appropriate behaviours (supervisor/manager, "does not make gender discrimination among workers"; "acts equal to every worker in distribution 
of tasks"; "does not make discrimination among workers with their preferences of thoughts, ideas, political"; "avoids from behaviours which insult the workers" etc.) A preliminary study was implemented for the questionnaire to examine the language appropriateness for the objective of the study, before implementing it to the target sampling under consideration. 124 questionnaires were administered to the students who received undergraduate degree in tourism education with experience as a trainee in tourism establishments. The reliability coefficient was calculated to be (Cronbach's Alpha) $\alpha$ : 0,85. A 5-point Likert scale, ranging from 1 denoting strongly disagree to 5 denoting strongly agree, was employed in the study.

The Minnesota Satisfaction Questionnaire - MSQ, developed by Weiss et al. (1967) containing 20 dimensions of job satisfaction, was employed in the study. It is a well-known fact that in a variety of studies on job satisfaction MSQ was employed (e.g. Marşap, 1995; Ünsal \& Türetgen, 2005; Avcı \& Karatepe, 2000; Telman, 1998; Ok, 2002; Hancer \& George, 2003; Herrera \& Lim, 2003; Blake et al., 2004; Olguntürk, 2005; Erel, 2005; Güçer \& Demirdağ, 2014). The dimensions of MSQ are as the followings; "expression ability, achievement, activity, advancement, authority, managerial policy and practices, pay, co-workers, creativity, independence, moral values, appreciation, responsibility, security, social benefits-facilities, social service, status, supervision(human relations), management (technical aspects), variety and working conditions" (Weiss et. al., 1967: 3). Minnesota Satisfaction Questionnaire is based on the hypothesis that job satisfaction derives from the individuals' needs and the work systems through which these need are expected to be met and in addition to the 20 dimensions there is general satisfaction, , which is dealt with as the 21 st dimension of the scale.

The scales under consideration were implemented through face-to-face interaction and subsequently reliability analysis was performed and the Cronbach's Alpha coefficient for the questionnaire of ethical behaviours was calculated to be $\alpha: 0,83$ and job satisfaction questionnaire $\alpha$ : 0,89 .

\subsection{Population and Sampling}

The population of the study is comprised of the employees at five-star hotels. Due to the limitations of time and costs in reaching the whole population under consideration, appropriate sampling techniques have been adopted to increase the representative power of the study. In determining the sample size, two clusters as city and holiday resort hotels were formed and the sampling of the study covered such cities as Antalya, Muğla and Aydın, holiday resort places, and İstanbul, Ankara and İzmir, densely populated cities in Turkey.

In determining the number of employees at hotels under consideration of the study, because there is no database available in calculating the population, the data published by Ministry of Tourism in 1993 in "Labour Survey in Hotel and Tourism Sector" (Ministry of Tourism, 1993: 83). According to the data the number of personnel per bed is 0,41 . The data of 2014 show that there are 485 five-star hotels with a total of 155593 rooms and 329725 beds Ministry of Culture and Tourism, 2014). This being the case, subsequent to the implementation of 
formulation (329725 number of beds x 0,41 personnel per bed), the total number of personnel has been calculated as 135187, which makes up the total population. The following sampling formula has been employed to determine the sampling number.

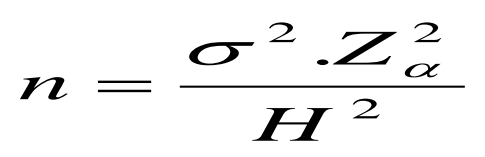

In the formula, the tolerance of error between the population and sampling was taken as $(\mathrm{H})$ $\pm 0,10$ and significance level was set as $(\alpha) 0,05$. On the other hand, the standarddeviation" $\sigma$ " was calculated as a result of the preliminary study administered to 120 participants. The sampling size for each group is $\alpha=0,05$ for $\mathrm{z}_{0,05}=1,96$ and $\sigma=1 \mathrm{H}= \pm 0,1$.

$$
n=\frac{1^{2} \cdot 1,96^{2}}{0,1^{2}}=384
$$

The yielding sample number is regarded for each group under consideration of the study. That is to say, 384 for city hotels and 384 for holiday resort hotels, which makes up 768 in total. Considering such factors as margin of error, erroneous coding, unreturned questionnaires, the number for each group was taken higher than 384. For this reason, for both groups a total of 850 questionnaires were administered and the number of questionnaires returned and deemed suitable for further analysis was 813 (336 for city hotels, 477 for holiday resort hotels). Table 1 reports some demographics on hotels in this study.

Table 1. Employee Questionnaires and Percentages used in the study by regions and cities

\begin{tabular}{|c|c|c|c|c|c|}
\hline \multirow{2}{*}{$\begin{array}{l}\text { The } \\
\text { Location of } \\
\text { Hotels }\end{array}$} & \multirow[t]{2}{*}{ City } & \multirow{2}{*}{$\begin{array}{c}\text { The Number of } \\
\text { Surveyed } \\
\text { Hotels }\end{array}$} & \multirow{2}{*}{$\begin{array}{l}\text { The Number } \\
\text { of Returned } \\
\text { Surveys }\end{array}$} & \multicolumn{2}{|c|}{$\begin{array}{l}\text { The Number of } \\
\text { Utilized Surveys }\end{array}$} \\
\hline & & & & $\mathbf{f}$ & $\%$ \\
\hline \multirow{4}{*}{ Resort Hotels } & Antalya & 14 & 235 & 232 & 25.8 \\
\hline & Muğla & 8 & 155 & 154 & 17.6 \\
\hline & Aydın & 4 & 93 & 91 & 10.5 \\
\hline & Subtotal & 26 & 483 & 477 & 58.7 \\
\hline \multirow{4}{*}{ City Hotels } & İstanbul & 10 & 154 & 153 & 20.2 \\
\hline & Ankara & 7 & 121 & 121 & 16.9 \\
\hline & İzmir & 3 & 64 & 62 & 9.1 \\
\hline & Subtotal & 20 & 339 & 336 & 41.3 \\
\hline \multicolumn{2}{|c|}{ Total } & 46 & 822 & 813 & 100 \\
\hline
\end{tabular}

\subsection{Data Analysis Method}

The data obtained from the study were analysed through some statistical tests. For example data on the appropriateness of the behaviour of managers to employees and the level of job satisfaction was assessed through frequency and percentage analysis and arithmetic averages and standard deviations for each statement were put in tables and interpreted. On the other 
hand, to tests whether there is difference between the appropriateness of the behaviour of managers to employees and the level of job satisfaction in terms of the types of hotels - city or resort- , $\mathrm{t}$-test for independent samples was employed

The relation between the ethical practices and job satisfaction was evaluated though "correlation analysis" and "Pearson correlation coefficient" was employed for each variable. The coefficients between 0-0,20 was regarded as very weak, $0,20-0,40$ weak, $0,40-0,60$ moderate, 0,60 - 0,80 strong/high and 0,80 - 1 very strong / high in the related literature (Çil, 2002; Büyüköztürk, 2003; Akgül \& Çevik, 2003). These values are considered in the analysis of the findings in this study, too.

As well as the regression analysis, the determination coefficient $\left(\mathrm{R}^{2}\right)$ has also been computed in order to find out the explanatory power of dependent variable (job satisfaction) on independent variable (ethical practices of managers). Determination coefficient is the coefficient that indicates to what extent a unit of change can be explained by other variables or to show the extent of dependency of variables under consideration to each other. The coefficient is between 0 and 1 and cannot be of negative value (Ural \& K1lıç, 2006: 249). On the other hand, linear regression analysis was implemented in order to calculate the effect of the ethical practices of managers on job satisfaction. Linear regression analysis is a statistical analysis with an aim to calculate the relation between variable through a mathematical model (Büyüköztürk, 2003: 94; Ural \& K1lıç, 2006: 253). Within this framework, the ethical practices of managers were taken as independent variables and the effect of these variables on "job satisfaction" was examined.

\section{Research Findings and Interpretation}

\subsection{Findings Related with Job Satisfaction Levels of Employees}

According to the demographic findings, $68,4 \%$ of the participants are male, $31,6 \%$ female and $10,9 \%$ hold a primary school degree and 57,3\% hold secondary school degree and 14,8\% hold university degree. 41,3 of the participants are employed at city hotels and $58,7 \%$ at holiday resort hotels. Table 2 reports the responses of the participants for each item in the scale.

As reported in Table 2, the averages for the items related to satisfaction are below 4 (satisfactory), and especially with such items In terms of having the chance to do something that makes use of my abilities" ( $\bar{X}=3,3$ ), "In terms of having the chance for advancement in this job" $(\bar{X}=3,4)$, "In terms of being always busy with my job in work" ( $\bar{X}=3,3)$, "In terms of feeling authorized to tell people what to do on this job" $(\bar{X}=3,4)$, "In terms of having the chance to try my own methods of doing my job" $(\bar{X}=3,4)$ and "In terms of my pay and the amount of work I do" ( $\bar{X}=3,4)$, the satisfaction averages are at its nadir. On the other hand, the items with highest averages are "In terms of the way my co-workers get along with each other" $(\bar{X}=4,0)$, "In terms of getting the praise when I do a good job" $(\bar{X}=3,9)$, "In terms of the sense of successfully completion on my works" $(\bar{X}=3,9)$ and "In terms of the competence of my supervisor in making decisions". 
The results mentioned in the above paragraph reveal that the participation level of the employees in decision making process are not at the desired level and emplo0yees are not content with the opportunity of conducting tasks independent of managerial polices. Employees state that the tasks they perform may sometimes deprive them of different tasks and this may be attributed to the fact that routinely-performed tasks might turn into monotonous ones, thus leading to boredom and dissatisfaction among employees. To overcome this, manager should adopt job enrichment and rotation activities to hamper the feeling of monotony.

Table 2. Frequency, percentage, arithmetic average and standard deviation values for each item of job satisfaction levels of employees

\begin{tabular}{|c|c|c|c|c|c|c|c|c|c|}
\hline My current job; & $\mathbf{n}$ & 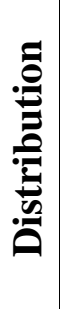 & 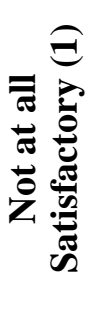 & 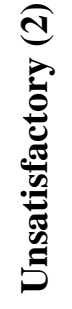 & 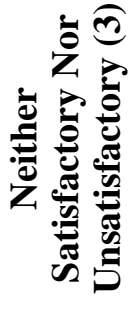 & 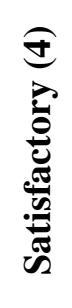 & 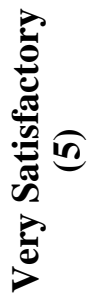 & $\mathrm{X}$ & s.d. \\
\hline \multirow{2}{*}{$\begin{array}{l}\text { In terms of the freedom to apply my own } \\
\text { decisions }\end{array}$} & \multirow{2}{*}{813} & $\mathrm{f}$ & 121 & 56 & 107 & 377 & 152 & \multirow{2}{*}{3,5} & \multirow{2}{*}{1,3} \\
\hline & & $\%$ & 14,9 & 6,9 & 13,2 & 46,4 & 18,7 & & \\
\hline \multirow{2}{*}{$\begin{array}{l}\text { In terms of the sense of successfully completion } \\
\text { on my works }\end{array}$} & \multirow{2}{*}{813} & $\mathrm{f}$ & 14 & 115 & 54 & 385 & 245 & \multirow{2}{*}{3,9} & \multirow{2}{*}{1,0} \\
\hline & & $\%$ & 1,7 & 14,1 & 6,6 & 47,4 & 30,1 & & \\
\hline \multirow{2}{*}{$\begin{array}{l}\text { In terms of having choice in doing the things } \\
\text { contrary to my conscience }\end{array}$} & \multirow{2}{*}{813} & $\mathrm{f}$ & 99 & 40 & 184 & 258 & 232 & \multirow{2}{*}{3,6} & \multirow{2}{*}{1,3} \\
\hline & & $\%$ & 12,2 & 4,9 & 22,6 & 31,7 & 28,5 & & \\
\hline \multirow{2}{*}{$\begin{array}{l}\text { In terms of being always busy with my job in } \\
\text { work }\end{array}$} & \multirow{2}{*}{813} & $\mathrm{f}$ & 191 & 43 & 97 & 294 & 188 & \multirow{2}{*}{3,3} & \multirow{2}{*}{1,5} \\
\hline & & $\%$ & 23,5 & 5,3 & 11,9 & 36,2 & 23,1 & & \\
\hline \multirow{2}{*}{$\begin{array}{l}\text { In terms of the possibilities of being permanent in } \\
\text { my work }\end{array}$} & \multirow{2}{*}{813} & $\mathrm{f}$ & 103 & 122 & 87 & 252 & 249 & \multirow{2}{*}{3,5} & \multirow{2}{*}{1,4} \\
\hline & & $\%$ & 12,7 & 15,0 & 10,7 & 31,0 & 30,6 & & \\
\hline \multirow{2}{*}{$\begin{array}{l}\text { In terms of feeling authorized to tell people what } \\
\text { to do on this job }\end{array}$} & \multirow{2}{*}{813} & $\mathrm{f}$ & 112 & 47 & 199 & 279 & 176 & \multirow{2}{*}{3,4} & \multirow{2}{*}{1,3} \\
\hline & & $\%$ & 13,8 & 5,8 & 24,5 & 34,3 & 21,6 & & \\
\hline \multirow{2}{*}{$\begin{array}{l}\text { In terms of having the chance to work alone on } \\
\text { my job }\end{array}$} & \multirow{2}{*}{813} & $\mathrm{f}$ & 128 & 67 & 112 & 318 & 188 & \multirow{2}{*}{3,5} & \multirow{2}{*}{1,3} \\
\hline & & $\%$ & 15,7 & 8,2 & 13,8 & 39,1 & 23,1 & & \\
\hline In terms of having the chance to do something & 813 & $\mathrm{f}$ & 213 & 61 & 73 & 200 & 266 & 33 & 16 \\
\hline that makes use of my abilities & 010 & $\%$ & 26,2 & 7,5 & 9,0 & 24,6 & 32,7 & 3,3 & 1,0 \\
\hline In terms of having the chance to try my own & 813 & $\mathrm{f}$ & 122 & 139 & 85 & 195 & 272 & 34 & 15 \\
\hline methods of doing my job & 010 & $\%$ & 15,0 & 17,1 & 10,5 & 24,0 & 33,5 & 3,4 & 1,0 \\
\hline In terms of having the chance to do things for & 813 & $\mathrm{f}$ & 26 & 142 & 154 & 278 & 213 & 36 & 11 \\
\hline other people on my job and environment & & $\%$ & 3,2 & 17,5 & 18,9 & 34,2 & 26,2 & & \\
\hline In terms of having the chance to be somebody in & 813 & $\mathrm{f}$ & 24 & 122 & 108 & 350 & 209 & 3.7 & 11 \\
\hline the community & & $\%$ & 3,0 & 15,0 & 13,3 & 43,1 & 25,7 & & \\
\hline In terms of having the chance to do different & 813 & $\mathrm{f}$ & 20 & 140 & 129 & 253 & 271 & 38 & 12 \\
\hline things from time to time on my job & 010 & $\%$ & 2,5 & 17,2 & 15,9 & 31,1 & 33,3 & 3,0 & 1,2 \\
\hline In terms of having the chance for advancement in & 806 & $\mathrm{f}$ & 121 & 130 & 111 & 216 & 228 & 34 & 14 \\
\hline this job & & $\%$ & 14,9 & 16,0 & 13,7 & 26,6 & 28,0 & 3,4 & 1,4 \\
\hline In terms of company policies into practice & 807 & $\mathrm{f}$ & 24 & 203 & 134 & 219 & 227 & 35 & 12 \\
\hline & 801 & $\%$ & 3,0 & 25,0 & 16,5 & 26,9 & 27,9 & & \\
\hline In terms of my nay and the amount of work I do & 813 & $\mathrm{f}$ & 64 & 157 & 168 & 221 & 203 & 3.4 & 13 \\
\hline 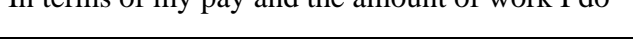 & & $\%$ & 7,9 & 19,3 & 20,7 & 27,2 & 25,0 & 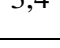 & 1,0 \\
\hline of oetting the nraise when Id & 812 & $\mathrm{f}$ & 35 & 119 & 83 & 260 & 315 & 39 & 2 \\
\hline In terms or getting the praise when I do a go & 812 & $\%$ & 4,3 & 14,6 & 10,2 & 32,0 & 38,7 & 3,9 & 1,2 \\
\hline
\end{tabular}




\begin{tabular}{|c|c|c|c|c|c|c|c|c|c|}
\hline \multirow{2}{*}{$\begin{array}{l}\text { In terms of the competence of my supervisor in } \\
\text { making decisions }\end{array}$} & \multirow{2}{*}{811} & $\mathrm{f}$ & 16 & 115 & 109 & 342 & 229 & \multirow{2}{*}{3,8} & \multirow{2}{*}{1,1} \\
\hline & & $\%$ & 2,0 & 14,1 & 13,4 & 42,1 & 28,2 & & \\
\hline \multirow{2}{*}{$\begin{array}{l}\text { In terms of the way my boss/supervisor handles } \\
\text { the workers }\end{array}$} & \multirow{2}{*}{813} & $\mathrm{f}$ & 23 & 123 & 77 & 337 & 253 & \multirow{2}{*}{3,8} & \multirow{2}{*}{1,1} \\
\hline & & $\%$ & 2,8 & 15,1 & 9,5 & 41,5 & 31,1 & & \\
\hline \multirow{2}{*}{$\begin{array}{l}\text { In terms of the working conditions (heating, } \\
\text { lighting, air conditioning etc.) }\end{array}$} & \multirow{2}{*}{806} & $\mathrm{f}$ & 41 & 123 & 15 & 195 & 289 & \multirow{2}{*}{3,7} & \multirow{2}{*}{2} \\
\hline & & $\%$ & 5,0 & 15,1 & 19 & 24,0 & 35,5 & & \\
\hline \multirow{2}{*}{$\begin{array}{l}\text { In terms of the way my co-workers get along with } \\
\text { each other }\end{array}$} & \multirow{2}{*}{813} & $\mathrm{f}$ & 20 & 40 & 17 & 291 & 285 & \multirow{2}{*}{4,0} & \multirow{2}{*}{1,0} \\
\hline & & $\%$ & 2,5 & 4,9 & 21,8 & 35,8 & 35,1 & & \\
\hline
\end{tabular}

There are a variety studies into the reason why employees are not satisfied with wages (Lawler \& Suttle, 1973; Schneider \& Alderfer, 1973; Churchill et al., 1976; Clark, 1996; Çarıkçı, 2001; Bruck et al., 2002; İnce, 2003; Uçkun et al., 2004; Gazioglu \& Tansel, 2006; Nadiri \& Tanova, 2010; Frye, 2012; Al-Ababneh, 2013; Güçer \& Demirdağ, 2014 etc.). In this era, the fact that establishments are faced with the problem of low wage is not only related to managerial polices but the level of social and economic development as well. To deal with this in a solution-focused manner, especially labour-intensive establishment should be in an attempt to support optional (performance overtime) or supportive (overtime pay, bonus, reward, etc.) and fair wage systems. The employee satisfaction, as a result, is not only associated with a bundle of new tasks, conditions and social benefits but also extra financial support they expect to have.

\subsection{Findings Related with Employees' Perceptions on the Applications of Managers in Business Ethics}

Table 3 reports the findings related with employees' perceptions on the applications of managers in business ethics. When the findings in Table 3 are considered, the arithmetic averages are between 3,5-4,00 ranging from "I moderately agree" to "I agree", with lowest average items being "takes precautions to protect workers from accidents at work" ( $\bar{X}=3,4)$, "supports the social security and social rights of workers" $(\bar{X}=3,6)$, "supports the workers on activities for unions" $(\bar{X}=3,4)$, "acts fair in evaluation of performance of workers" $(\bar{X}=3,5)$, "does not force the workers to work without paying after/before shift" $(\bar{X}=3,6)$, "creates an environment for workers to provide rights to participate in decision" $(\overline{\mathrm{X}}=3,6)$, "acts positive when the workers comment and/or make suggestions about work" ( $\overline{\mathrm{X}}=3,6)$. Considering the fact that the items are related to the participation in decision making processes and social security benefits, it is possible to assert that managers are not sensitive to these issues and this could be linked to the legislative issues in the country. Hence, it might be suggested that managers should be more understanding and salient in these issue, since the issues under consideration are the cornerstones of the contemporary managerial concept. Taking the labour-sensitive nature of hotels, customers ask for responsive service delivery, and hence meeting the swift service delivery request of the customers could be possible through self-decision processes, in other words, waiting for the managers to take an action against a specific event is very time consuming, this being the case, employees should be given some room to act on their initiatives to create customer satisfaction and fast service delivery, one of the dimensions of service quality. 
Table 3. Frequency, percentage, arithmetic average and standard deviation values for each item on employees' perceptions on the applications of managers in business ethics

\begin{tabular}{|c|c|c|c|c|c|c|c|c|c|}
\hline The Supervisor/Manager who I work together; & $\mathbf{n}$ & 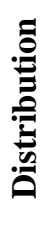 & 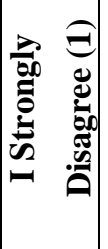 & 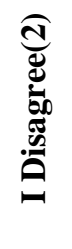 & 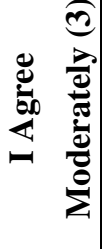 & 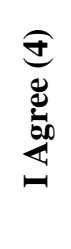 & 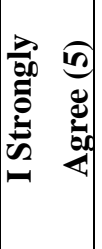 & $\mathrm{X}$ & s.d. \\
\hline \multirow{2}{*}{$\begin{array}{l}\text { Does not make gender discrimination among } \\
\text { workers }\end{array}$} & \multirow{2}{*}{813} & $\mathrm{f}$ & 121 & 35 & 140 & 140 & 377 & \multirow{2}{*}{3,7} & \multirow{2}{*}{1,4} \\
\hline & & $\%$ & 14,9 & 4,3 & 17,2 & 17,2 & 46,4 & & \\
\hline \multirow{2}{*}{$\begin{array}{l}\text { Does not let the sexual harassment occurred/may } \\
\text { occur in work }\end{array}$} & \multirow{2}{*}{813} & $\mathrm{f}$ & 20 & 107 & 33 & 302 & 351 & \multirow{2}{*}{4,0} & \multirow{2}{*}{1,1} \\
\hline & & $\%$ & 2,5 & 13,2 & 4,1 & 37,1 & 43,2 & & \\
\hline \multirow{2}{*}{ Acts fair to every worker in distribution of tasks } & \multirow{2}{*}{813} & $\mathrm{f}$ & 99 & 37 & 45 & 311 & 321 & \multirow{2}{*}{3,8} & \multirow{2}{*}{1,3} \\
\hline & & $\%$ & 12,2 & 4,6 & 5,5 & 38,3 & 39,5 & & \\
\hline \multirow{2}{*}{$\begin{array}{l}\text { Does not make discrimination among workers } \\
\text { with their preferences of thoughts, ideas, political }\end{array}$} & \multirow{2}{*}{813} & $\mathrm{f}$ & 20 & 43 & 160 & 228 & 362 & \multirow{2}{*}{4,0} & \multirow{2}{*}{1,0} \\
\hline & & $\%$ & 2,5 & 5,3 & 19,7 & 28,0 & 44,5 & & \\
\hline \multirow{2}{*}{$\begin{array}{l}\text { Gives an equal opportunity to every worker on } \\
\text { advancement }\end{array}$} & \multirow{2}{*}{813} & $\mathrm{f}$ & 27 & 36 & 141 & 382 & 227 & \multirow{2}{*}{3,9} & \multirow{2}{*}{0,9} \\
\hline & & $\%$ & 3,3 & 4,4 & 17,3 & 47,0 & 27,9 & & \\
\hline \multirow{2}{*}{ Does not interfere in private life of workers } & \multirow{2}{*}{813} & $\mathrm{f}$ & 17 & 9 & 198 & 242 & 347 & \multirow{2}{*}{4,0} & \multirow{2}{*}{0,9} \\
\hline & & $\%$ & 2,1 & 1,1 & 24,4 & 29,8 & 42,7 & & \\
\hline \multirow{2}{*}{$\begin{array}{l}\text { Does not decipher specific information of workers } \\
\text { in any environment }\end{array}$} & \multirow{2}{*}{813} & $\mathrm{f}$ & 24 & 90 & 126 & 221 & 352 & \multirow{2}{*}{3,9} & \\
\hline & & $\%$ & 3,0 & 11,1 & 15,5 & 27,2 & 43,3 & & \\
\hline A yoids hohoxiou & $812+3$ & $\mathrm{f}$ & 28 & 116 & 73 & 318 & 277 & 38 & 1 \\
\hline 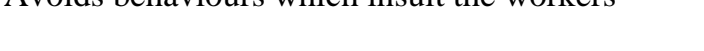 & 012 & $\%$ & 3,4 & 14,3 & 9,0 & 39,1 & 34,1 & $\mathrm{J,O}$ & 1,1 \\
\hline Takes precautions to protect workers from & $812+3$ & $\mathrm{f}$ & 74 & 155 & 133 & 209 & 242 & & \\
\hline accidents at work & & $\%$ & 9,1 & 19,1 & 16,4 & 25,7 & 29,8 & ד ד & I, \\
\hline 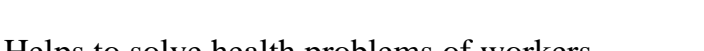 & 81 & $\mathrm{f}$ & 48 & 127 & 80 & 239 & 319 & & P \\
\hline & O1J & $\%$ & 5,9 & 15,6 & 9,8 & 29,4 & 39,2 & $J, 0$ & 1,2 \\
\hline Supports the social security and social rights of & 8 & $\mathrm{f}$ & 68 & 147 & 60 & 253 & 285 & 6 & 2 \\
\hline workers & 010 & $\%$ & 8,4 & 18,1 & 7,4 & 31,1 & 35,1 & $J, 0$ & 1,0 \\
\hline $\mathrm{C}_{\mathrm{u}} \mathrm{C}_{\mathrm{C}}$ & 8 & $\mathrm{f}$ & 78 & 146 & 204 & 127 & 258 & 24 & 2 \\
\hline supports tile workers on activilies ior untors & 015 & $\%$ & 9,6 & 18,0 & 25,1 & 15,6 & 31,7 & 3,4 & 1,5 \\
\hline & & $\mathrm{f}$ & 116 & 40 & 170 & 231 & 256 & & \\
\hline 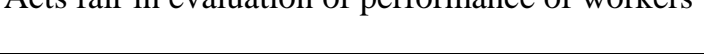 & 010 & $\%$ & 14,3 & 4,9 & 20,9 & 28,4 & 31,5 & (נ, & 1,0 \\
\hline Does not force the workers to work without & & $\mathrm{f}$ & 139 & 45 & 95 & 196 & 338 & & \\
\hline paying after/before shift & & $\%$ & 17,1 & 5,5 & 11,7 & 24,1 & 41,6 & & \\
\hline Creates an environment for workers to provide & & $\mathrm{f}$ & 55 & 146 & 122 & 198 & 292 & & \\
\hline rights to participate in decision & & $\%$ & 6,8 & 18,0 & 15,0 & 24,4 & 35,9 & & \\
\hline Does not make discrimination among workers in & & $\mathrm{f}$ & 14 & 53 & 116 & 217 & 413 & & \\
\hline religious, linguistic and racial terms & & $\%$ & 1,7 & 6,5 & 14,3 & 26,7 & 50,8 & & \\
\hline Acts positive when the workers to comment & 813 & $\mathrm{f}$ & 107 & 75 & 82 & 269 & 280 & 3,6 & 1,3 \\
\hline
\end{tabular}




\begin{tabular}{|c|c|c|c|c|c|c|c|c|c|}
\hline and/or to make suggestions about work & & $\%$ & 13,2 & 9,2 & 10,1 & 33,1 & 34,4 & & \\
\hline \multirow{2}{*}{$\begin{array}{l}\text { Cares the courtesy in all types of communication } \\
\text { with workers }\end{array}$} & \multirow{2}{*}{813} & f & 108 & 17 & 81 & 234 & 373 & \multirow{2}{*}{9} & \multirow{2}{*}{1,3} \\
\hline & & $\%$ & 13,3 & 2,1 & 10,0 & 28,8 & 45,9 & & \\
\hline
\end{tabular}

Besides, the employees will adopt the notion of achievement though sorting out a problem, which is likely to lead to further job satisfaction due to the feeling of being a part of the establishment and achievement.

4.4 Findings Related to the Assessments of Job Satisfaction Level and Ethical Practices of Managers by Location

Table 4 reports the findings of $t$ test on the assessments of job satisfaction level and ethical practices of managers by location of hotels. As can be seen from the Table 4, there is a statistically significant difference between the job satisfaction level of employees and ethical practices of managers at 0,001 significance level $(\mathrm{p}<0,001)$.

Table 4. The results of $t$ test on job satisfaction level and ethical practices of managers by location of hotels

\begin{tabular}{|c|c|c|c|c|c|c|}
\hline & $\begin{array}{c}\text { The } \\
\text { Location of } \\
\text { Hotels }\end{array}$ & $\mathbf{N}$ & $\bar{X}$ & s.d. & t & P \\
\hline $\begin{array}{c}\text { Job } \\
\text { Satisfaction }\end{array}$ & City & 336 & 3,85 & 0,92 & \multirow{2}{*}{6,452} & $\mathbf{0 , 0 0 0 *}$ \\
\cline { 2 - 5 } & Resort & 477 & 3,43 & 0,91 & \multirow{2}{*}{4,678} & $\mathbf{0 , 0 0 0 *}$ \\
\hline $\begin{array}{c}\text { The Business } \\
\text { Ethics } \\
\text { Behaviours of } \\
\text { Managers }\end{array}$ & City & 336 & 3,97 & 0,90 & 0,82 & \\
\cline { 2 - 6 } & Resort & 477 & 3,69 & 0,69 & \\
\hline
\end{tabular}

"p $<0,001$

The arithmetical averages presented in Table 4 show that the assessments of the employees on ethical behaviour of managers at city hotels are more positive $(\bar{X}=3,85)$ than those at holiday-resort hotels $(\bar{X}=3,43)$. This result could be put down to the fact that holiday-resort hotels operate seasonally and hence the ethical implementations are not considered important and with the next season and new hotel staff there will be a new beginning, which underestimate the notion of institutionalization, leaving no path for ethical considerations. On the other hand, city hotels usually operate on a 12-month basis with an understanding of institutionalization, hence paving way for ethical considerations. Furthermore, the number of personnel employed at holiday resort hotels is higher than city hotels and the variety of works to be performed are more, which could lead the implementation of ethical practices in 
an unfulfilled manner as well as at the desired level. The facts that job satisfaction levels and the ethical aspects of managerial implementations are at lower levels are points of importance to be addresses with peculiar attention. Especially, it is inevitable that the holiday-resort hotels, the contributions of which are more to the tourism, should align the ethical practices and job satisfaction to the desired levels. Holiday-resort hotels should not only enhance the benefits for employees but involve employees in managerial and policy-related decisions, for a contemporary management concept relies on the understanding that "the expert knows the best in the job performed" and the winner in this case will be the management by means of making the most of the experience of employees under consideration.

\subsection{Findings Related of the Effect of Ethical Practices of Managers on Job Satisfaction}

Table 5 reports the results of correlation matrix and regression analysis of the effect of ethical practices of managers on job satisfaction. In the correlation analysis, job satisfaction (JS) was taken as dependent variable and the behaviour of managers (EPM) as independent variable.

Table 5. Correlation Matrix and Regression Analysis between the Managers' Behaviours Relating to Business Ethics and Employees' Job Satisfaction

\begin{tabular}{|c|c|c|c|c|c|c|c|}
\hline $\begin{array}{l}\text { Independent } \\
\text { Variables }\end{array}$ & $\boldsymbol{\beta}_{\mathbf{j}}$ & $\mathbf{S}\left(\mathbf{b}_{\mathbf{j}}\right)$ & $\mathbf{t}$ & $\mathbf{p}$ & $\mathbf{r}$ & $\mathbf{R}^{2}$ & $\mathbf{p}$ \\
\hline Fixed & 1,088 & 0,118 & 9,228 & $\mathbf{0 , 0 0 0}{ }^{*}$ & \multirow{2}{*}{$0,609^{*}$} & \multirow{2}{*}{0,370} & \multirow{2}{*}{$\begin{array}{l}\mathrm{F}=477,077 \\
\mathbf{p}=\mathbf{0 , 0 0 0}\end{array}$} \\
\hline EPM & 0,660 & 0,030 & 21,842 & $\mathbf{0 , 0 0 0}{ }^{*}$ & & & \\
\hline
\end{tabular}

": p<0,001; Dependent Variable: JS: Job Satisfaction, EPM: The Business Ethics Behaviours of Managers; $r$ :Correlation Coefficient $R^{2}$ :Determination Coefficient

The findings presented in Table 5 indicate that there is a statistically significant relationship at 0,001 significance level between ethical behaviour of managers and job satisfaction of employees. In other words, "Pearson Correlation Coefficient (r)" is significant between the variables under consideration $(\mathrm{p}<0,001)$. As seen in Table 5, there is a high correlation $(\mathrm{r}=0,609)$ between the ethical practices of mangers and employee job satisfaction $(0,60<r<0,80)$. When the determination coefficient $\left(R^{2}\right)$ is examined in Table $5,37 \%$ of the total variance stems from the ethical practices of managers. According to this, the ethical practices of managers are of great significance in terms of hob satisfaction of employees. On the other hand, the correlation analysis performed does not lend itself to be interpreted as a cause-effect relationship (Büyüköztürk, 2003: 34).

The analysis accounts for the direction and the power of the correlation between the variables under consideration. To further analyse, in order to bring a mathematical model explaining 
the relation between the variables, and regression analysis has been performed and the results are also presented in Table 5. Table reports that the regression model of job satisfaction level and the ethical practices of managers is statistically significant $(F=477,077 ; p<0,001)$. Considering this, $\mathrm{H}_{0}$ hypothesis $\left(\mathrm{H}_{0}: \beta_{\mathrm{j}}=0\right)$ that the regression coefficient equals to 0 is rejected. That is to say, the regression coefficient is different from 0 . Taking determination coefficient $\left(\mathrm{R}^{2}=0,370\right)$ into account, $37 \%$ of the total variance in job satisfaction comes from the independent variable (ethical practices of managers). This is in line with the determination coefficient presented in Table 5 and yields supporting results in terms of the significance of the model.

According to Table 5, the regression model related to the effect of the independent variable -ethical practices of managers (EPM)- on the dependent variable -job satisfaction (JS)- is as the following;

$$
\mathrm{JS}=1,088+0,660 . \mathrm{EPM}
$$

To sum up, as the results of the analyses presented thus far, there is a significant relationship between the ethical behaviours of managers in managerial context and the employee job satisfaction. This relation shows that as more managers align their behaviour in ethics, the higher is job satisfaction. The findings within this scope support the hypothesis that ethical behaviours of managers affect job satisfaction in a positive manner, and the hypothesis is supported.

\section{Conclusion and Suggestions}

No matter what field of business a firm may operate in, attitude and behaviour of human resources of a given business are of greater importance than the whole technological and other resources. It is the human resources that will make the wheel keep turning no matter how modern and technological an establishment is equipped, which underpins the strategic importance of human resources. Within a historical perspective of managerial approach, there have been developments on behalf of employees and the efforts to advance management methods and techniques have accelerated even more. The fierce competitive settings and ever-changing business environment make establishment to be prone to new threats and opportunities alike. Hence, managers should feel obliged to be knowledgeable and equipped with the newly-developed managerial approaches and reflect these in their business settings.

The points mentioned above come forefront especially in the sectors where labour-intensive products are mainly offered, for the labour-intensive nature very much rests with the human factor and any new technique developed for employees will provide them with advantageous prospects. To serve his purpose, managers play some key roles. Furthermore, the behaviours of managers towards employees are among the factors that will shape the results of the service delivery of employees. Especially, ethical practices and behaviours of managers are of great significance from the points of employees and hence the organization. Within this framework, this paper set out to examine and ethical assessment of the behaviour of managers of hotels and the effect of ethical behaviours on job satisfaction of employees. 
A majority of the employees stated that managers were not quite ethical in such issues as "accidents at work", "social security", "participation in unions", "fairness in performance evaluation", "participation in decision", "ideas of workers", "payment in overtime". On the other hand, employees stated that they very not quite satisfied with such issues as ; "promotion opportunities", "payment", "opportunity of working alone", "opportunity of participation in decisions".

Another result brought forth by the study is that the perception of the employees on the assessment of ethical practices at city hotels is more positive than those at resort hotels. The number of personnel at resort hotels are usually more than the city hotels and the tasks to be performed are more diverse especially in the high season and for these reasons the level of job satisfaction might be lower, for any employee might be assigned any tasks without the experience or expertise. Since the main objective is rather to complete the tasks within a given amount of time, this could bring about some ethical issues. On the other hand, ethical consideration exerted by managers and thus ethical practices will give rise to a rise in the more of the employees and enhance their mood, leading to a higher job satisfaction. As a matter of fact, the analyses conducted within the scope of this paper reveal a high correlation $(r=0,609),(0,60<r<0,80)$ between ethical behaviours of managers and job satisfaction levels of employees and regression analysis also support this point.

The issue of job satisfaction of great significance at labour-focus nature of service sector where service delivery is performed in a face-to-face manner and customer satisfaction is greatly influenced by the manner service is delivered. Customers are usually in the pursuit of responsive service delivery. A job-satisfied employee holds a great advantage in terms of offering a variety of alternatives to customers who seem to be discontent. Due to the face-to-face nature of service delivery, customer complaints are directly communicated to employees offering services. This could lead to stress and conflicts among the employees, extending further to managers. At this point the attitude of the managers' will have either a positive or negative effect on the motivation and satisfaction of employees. Besides, a work setting aligned by ethical principles will enhance job satisfaction as well as organizational trust and commitment.

The most important element in the service delivery at hotels is the human resources. Among the human resources, employees are of special place, for products are delivered through employees. The service given is affected by not only the establishment-related settings but also by the way employees deliver services. On the other hand, it will be inevitable that the attitude of the employees with no job satisfaction will be reflected on the performance and thus on customers. Therefore, hotel management should activate the factors underlined in detail in this paper in order to enhance job satisfaction. The ethical behaviours of managers toward employees are among the factors and one of the results presented in this paper. In this context, a comprehensive analysis of the conclusions put forward in this study is thought to contribute to the accomplishment of organizational objectives and efficiency of hotel establishments. 


\section{References}

Akgül, A. \& Çevik, O. (2003). İstatistiksel Analiz Teknikleri, "SPSS'te İşletme Yönetimi Uygulamaları". (1st ed.). Ankara: Emek Publish.

Akıncı, Z. (2002). Turizm Sektöründe İşgören İş Tatminini Etkileyen Faktörler: Beş Yıldızlı Konaklama İşletmelerinde Bir Uygulama. Akdeniz University Faculty of Economics and Administrative Sciences Journal, 2(4), 1-25.

Akoğlan, M. \& Kozak, N. (1995). Otel İşletmelerinde Personel Kullanım Alanları Üzerine Bazı Gözlemler. Anatolia: An International Journal of Tourism and Hospitality Research, 6(2), 36-39.

Al-Ababneh, M. (2013). Leadership Style of Managers in Five-Star Hotels and its Relationship with Employee's Job Satisfaction. International Journal of Management \& Business Studies, 3(2), 93-98.

Altuğ, N. \& Güler, E. G. (2003). Pazarlama Etiği: Hizmet Pazarlamasında Karşılaşılan Etik Sorunlar ve Malların Pazarlanmasından Farklılıkları, The Report of First Turkey International Work and Profession Ethics Congress, Ankara: Hacettepe University Management of Professional Ethics Applications and Research Centre, 17-19 September: 321-327.

Altunışık, R., Coşkun, R., Bayraktaroğlu, S. \& Yıldırım, E. (2004). Sosyal Bilimlerde Araştırma Yöntemleri: SPSS Uygulamalı. (1st ed.). Sakarya: Sakarya Bookstore.

Arıkan, E. (2011). Örgüt Sağllğının İş Tatmini Üzerine Etkisi: Afyonkarahisar'daki Beş Yıldızlı Otel Isşletmelerinde Bir Uygulama. Unpublished Master Thesis. Afyon Kocatepe University Institute of Social Sciences, Afyonkarahisar.

Arvey R. D., Bouchard T. J., Segal, N. L., \& Abraham, L. M. (1989). Job Satisfaction: Environmental and Genetic Components. Journal of Applied Psychology, 74(2), 187-192.

Avcı, T., \& Karatepe, O. M. (2000). İşletmenin Sınır Biriminde Çalışan İşgörenlerin Tatmini: Ampirik Bir Değerlendirme. 8th National Congress of Management and Organization. p.p. 543-570. Istanbul: Istanbul University.

Aydın, İ. (2002). Yönetsel, Mesleki ve Örgütsel Etik(3rd ed.). Ankara: Pegem Publishing.

Bakan, İ., \& Büyükbeşe, T. (2004). Örgütsel İletişim ile İş Tatmini Unsurları Arasındaki İlişkiler: Akademik Örgütler İçin Bir Alan Araştırması. Akdeniz University Faculty of Economics and Administrative Sciences Journal, 4(7), 1-30.

Baysal, A. C., \& Tekarslan, E. (1996). İşletmeciler Iç̧in Davranış Bilimleri. (2nd ed.). Istanbul: Avciol Print Publish.

Blake, S. S., Kester, L., \& Stoller, J. K. (2004). Respiratory Therapists' Attitudes About Participative Decision Making: Relationship Between Managerial Decision-Making Style and Job Satisfaction. Respiratory Care, 49(8), 917-925. 
Blegen, M. A. (1993). Nurses' Job Satisfaction: A Meta-Analysis of Related Variables. Nursing Research, 42(1), 36-41.

Boyer, E. P., \& Webb, T. G. (1992). Ethics and Diversity: A Correlation Enhanced Through Corporate Communication. Professional Communication, IEEE Transactions, 35(1), 38-43.

Bozkurt, Ö., \& Bozkurt, İ. (2008). İş Tatminini Etkileyen İşletme İçi Faktörlerin Eğitim Sektörü Açısından Değerlendirilmesine Yönelik Bir Alan Araştırması. Doğuş University Journal, 9(1), 1-18.

Brief, A. P. (1998). Attitudes in and Around Organizations. (1st ed.). USA: Sage Publications, Inc.

Bruck, C. S., Allen, T. D., \& Spector, P. E. (2002). The Relation Between Work-Family Conflict and Job Satisfaction: A Finer Grained Analysis. Journal of Vocational Behaviour, 60(2002), 336-353.

Budak, G. (1998). Yenilikçi Yönetim Yaratıcı Birey. (1st ed.). Istanbul: Sistem Publishing.

Büyüköztürk, Ş. (2003). Sosyal Bilimler İçin Veri Analizi El Kitabı: İstatistik, Araştırma Deseni SPSS Uygulamaları ve Yorum (2nd ed.). Ankara: Pegem AkademyPublishing.

Çarıkçı, İ. H. (2001). Çalışanlarda İş Tatminini Etkileyen Kişisel Özellikler ve Örgütsel Sonuçları: Süpermarket Çalışanları Üzerinde Bir Araştırma. Verimlilik Dergisi, 2001(4), 161-168.

Cherrington, D. J. (1994) Organizational Behavior: The Management of Individual and Organizational Performance. (2nd ed.). Boston: Allyin and Bacon.

Churchill, G. A., Ford, N. M., \& Walker, O. C. (1976). Organizational Climate and Job Satisfaction in The Sales Force. Journal of Marketing Research, 13(4), 232-332.

Çil, B. (2012). Istastistik. (7th ed.). Ankara: Detay Publishing.

Clark, A. E. (1996). Job Satisfaction in Britain. British Journal of Industrial Relations, 34 (2), 189-217.

Curran, J., \& Stanworth, J. (1981). A New Look at Job Satisfaction in The Small Firm. Human Relations, 34(5), 343-365.

Davis, D., \& Cosenza, R. M. (1998). Business Research for Decision Making. (1st ed.). Boston: PWS-Kent Publishing Company.

Davis, K. (1984). Işsletmelerde İnsan Davranışı. “Translated by Kemal Tosun” (1st ed.). Istanbul: Istanbul University School of Business Publications.

Davis-Blake, A., \& Pfeffer, J. (1989). Just a Mirage: The Search for Dispositional Effects in Organizational Research. The Academy of Management Review, 14(3), 385-400.

Erdil O., Keskin H., İmamoğlu, S. Z. \& Erat, S. (2004). Yönetim Tarzı ve Çalışma 
Koşulları, Arkadaşlık Ortamı ve Takdir Edilme Duygusu İle İş Tatmini Arasındaki İlişkiler: Tekstil Sektöründe Bir Uygulama. Doğuş University Journal, 5(1), 17-26.

Erdoğan, İ. (1999). İşletmelerde Davranış. (Publication Nr: 242). Istanbul: Istanbul University School of Business Publications.

Erel, E. (2005). İlköğretim Okullarında Görev Yapan Branş Öğretmenlerinin İs Doyumlart: Ankara İli Örneği. Unpublished Master Thesis. Gazi University Institute of Educational Sciences, Ankara.

Eren, E. (1998). Örgütsel Davranış ve Yönetim Psikolojisi. (5th ed.). Istanbul: Beta Publications.

Erez, M. (1994). Toward a Model of Cross-Cultural Industrial and Organizational Psychology. In H. C. Triandis, M. D. Dunette, L. M. Hough (Eds.). Handbook of Industrial and Organizational Psychology, 4(1), 559-608. Palo Alto, CA: Consulting Psychologist Press.

Ergün, Ö. (2005). Otel İşletmelerinin Pazarlama Faaliyetlerinde Etik (İstanbul'da Faaliyet Gösteren Beş Yıldızlı Otel Işsletmeleri Örneği). Unpublished Master Thesis. Sakarya University Institute of Social Sciences, Sakarya.

Ferrel, O. C. \& Fraedrich, J. (1991).Business Ethics: Ethical Decision Making and Cases. (1st ed.). Boston: Houghton Mifflin Company.

Fox, J. (2000). Approaching Managerial Ethical Standards in Croatia's Hotel Industry. International journal of contemporary hospitality management, 12(1), 70-74.

Frederick, W. C., Davis, K. \& Post, J. E. (1988). Business and Society: Corporate Strategy, Public Policy, Ethics. (6th ed.). New York: McGraw-Hill Publishing Company.

Frye, W. D. (2012). An Examination of Job Satisfaction of Hotel Front Office Managers According to Extrinsic, Intrinsic, and General Motivational Factors. International Journal of Business and Social Science, 3(18), 40-52.

Gazioglu, S. \& Tansel, A. (2006). Job Satisfaction in Britain: Individual and Job Related Factors. Applied Economics, 38(2006), 1163-1171.

Greenberg, J. \& Baron, R. A. (1995). Behaviour in Organizations: Understanding and Managing The Human Side of Work. (5th ed.). U.S.A: Prentice-Hall College Div.

Griffin, M. L. (2001). Job Satisfaction Among Detention Officers: Assessing the Relative Contribution of Organizational Climate Variables. Journal of Criminal Justice, 29(3), 219-232.

Güçer, E. \& Demirdağ, Ş. A. (2014). Organizational Trust and Job Satisfaction: A Study on Hotels. Business Management Dynamics, 4(1), 12-28.

Hancer, M. \& George, T. (2003). Job Satisfaction of Restaurant Employees: An Empirical Investigation Using The Minnesota Satisfaction Questionnaire. Journal of Hospitality \& 
Tourism Research, 27(1), 85-100.

Hatcher, T. (2004). Environmental Ethics As An Alternative For Evaluation Theory in For-Profit Business Context. Evaluation And Program Planning, 27(3), 357-363.

Herrera, R. \& Lim, J. Y. (2003). Job Satisfaction Among Athletic Trainers in NCAA Division Iaa Institutions. The Sport Journal, 6(1), 1-7.

House, R. J., Shane, S. A. \& Herold, D. M. (1996). Rumors of The Death of Dispositional Research Are Vastly Exaggerated. Academy of Management Review, 21(1), 203-224.

Huimin, G. \& Ryan, C. (2011). Ethics and Corporate Social Responsibility-An Analysis Of The Views of Chinese Hotel Managers. International Journal of Hospitality Management, 30(4), 875-885. http://dx.doi.org/10.1016/j.ijhm.2011.01.008

Ilies, R. \& Judge, T. A. (2002). Understanding The Dynamic Relationships Among Personality, Mood and Job Satisfaction: A Field Experience Sampling Study. Organizational Behavior and Human Decision Processes, 89(2), 1119-1139.

İnce, Ö. (2003). İş Tatminine Etki Eden Başlıca Etkenler ve Uygulamadan Bir Örnek. Unpublished Master Thesis. Marmara University Institute of Social Sciences, İstanbul.

İncir, G. (1990). Çalışanların İş Doyumu Üzerine Bir İnceleme. (Publication Nr: 401). Ankara: National Productivity Centre Publications.

İşseveroğlu, G. (2001). İşletmelerde Sosyal Sorumluluk ve Etik. Celal Bayar University F.E.A.S. Journal of Management and Economics, 8(2), 55-67.

Jazsay, C. (2002). An Integrated Research Review of Ethics. Northern Arizona University Hospitality Journals, 2000 to 2001.

Judge, T. \& Bono, J. E. (2001). Relationship of Core Self-Evaluations Traits-Self-Esteem, Generalized Self-Efficacy, Locus of Control, and Emotional Stability-with Job Satisfaction and Job Performance: A Meta Analysis. Journal of Applied Psychology, 86(1), 80-92.

Judge, T. A., Heller, D. \& Mount, M. K. (2002). Five-Factor Model of Personality and Job Satisfaction: A Meta-Analysis. Journal of Applied Psychology, 87(3), 530-541.

Kanbay, A. (2010). Hemşirelerin İş Doyumu ve Örgütsel Bağlılı̆̆g. Unpublished Master Thesis. Haliç University Institute of Health Sciences, Istanbul.

Kantarc1, K. (1997). Otel İşletmelerinde Işs Tatmininin Ölçülmesi ve Işsgören Performansına Etkileri. Unpublished Doctoral Thesis. Dokuz Eylül University Institute of Social Sciences, Izmir.

Kılınç İ. (2000). İş Etiki Kapsamında Otel Yöneticilerinin Çalışanlara Karşı Etik Sorumluluklarının İzmir'de Turizm İşletmeciliği ve Otelcilik Öğrenimi Gören Öğrencilerin Bakış Açıları ile Değerlendirilmesi. Dokuz Eylül University The Journal of Graduate School of Social Sciences, 2(3), 3-6. 
Kim, W. G. \& Brymer, R. A. (2011). The Effects of Ethical Leadership on Manager Job Satisfaction, Commitment, Behavioural Outcomes, and Firm Performance. International Journal of Hospitality Management, 30(4), 1020-1026. http://dx.doi.org/10.1016/j.ijhm.2011.03.008

Kırel, Ç. (2000). Örgütlerde Etik Davranışlar, Yönetimi ve Bir Uygulama Çalışması. (1st ed.). Eskişehir: Anadolu University Press.

Klein, J. \& Dawar, N. (2004). Corporate Social Responsibility and Consumers' Attributions and Brand Evaluations in A Product-Harm Crisis. International Journal of Research in Marketing, 21(3), 203-217.

Kozak, M. \& Karakaş, G. (2003). Otel İşletmelerinde Çalışan Servis Personelinin Etik Davranılan Üzerine Bir Araştırma. Journal of Tourism Academic, 2 (2003), 1-16.

Kuşluvan, Z. \& Kuşluvan, S. (2005). Otel İşletmelerinde İş ve İşletme İle İlgili Faktörlerin İşgören Tatmini Üzerindeki Görece Etkisi: Nevşehir Örneği. Anatolia: An International Journal of Tourism and Hospitality Research, 16(2), 183-203.

Kwansa, F. A. \& Farrar, A. L. (1992).A Conceptual Framework for Developing a Hospitality Educators' Code of Ethics. Hospitality Research Journal, 15(3), 27-39.

Lam, T., Pine, R. \& Baum, T. (2003). Subjective Norms: Effects on Job Satisfaction. Annals of Tourism Research, 30 (1), 160-177.

Lam, T., Zhang, H. \& Baum, T. (2001). An Investigation of Employees' Job Satisfaction: The Case of Hotels in Hong Kong. Tourism Management, 22(2), 157-165.

Lamberton, H. \& Minor, L. (1995). Human Relations: Strategies for Success. (1st ed.). Chicago: Irwin Mirror Press.

Lämsä, A. M. \& Pučètaitè, R. (2006). Development of Organizational Trust Among Employees from a Contextual Perspective. Business Ethics: European Review, 15(2), 130-141.

Lawler, E. E. \& Suttle, J. L. (1973). Expectancy Theory and Job Behaviour. Organizational Behaviour and Human Performance, 9(1973), 482-503.

Locke, E. A. (1976). The Nature and Causes of Job Satisfaction. In M. D. Dunnette (ed.), Handbook of Industrial and Organizational Psychology. Chicago: Rand-McNally.

Locke, E. A. (1991). The Motivation Sequence, The Motivation Hub and the Motivation Core. Organizational Behaviour \& Human Decision Processes, 50(2), 288-299.

Lu, H., While, A. E. \& Barriball, K. L. (2005). Job Satisfaction Among Nurses: A Literature Review. International Journal of Nursing Studies, 42(2), 211-227.

Marşap, B. (1995). Muhasebe Mesleğinde İş Tatmininin Türkiye Açısından Incelenmesi. Unpublished Doctoral Thesis. Gazi University Institute of Social Sciences, Ankara. 
McNamara, C. (2004). Complete Guide to Ethics Management: An Ethics Toolkit for Managers. [Online]

Available: https://www1.toronto.ca/inquiry/inquiry_site/cd/gg/add_pdf/77/Conflict_of_Interest/Electroni c_Documents/Research_orgs/Complete_Guide_to_Ethics_Mgt.PDF (December 29, 2015).

Motowidlo, S. J. (1996). Orientation Toward the Job and Organization: A Theory of Individual Differences in Job Satisfaction. In Individual Differences and Behaviour in Organizations. K. R. Murphy (Editors). p.p. 175-208. San Francisco: Jossey-Bass.

Nadiri, H. \& Tanova, C. (2010). An Investigation of The Role of Justice in Turnover Intentions, Job Satisfaction, and Organizational Citizenship Behaviour in Hospitality Industry. International Journal of Hospitality Management, 29(2010), 33-41.

Ok, S. (2002). Banka Çalışanlarının Tükenmişlik Düzeylerinin İş Doyumu, Rol Çatışması, Rol Belirsizliği ve Bazı Bireysel Özelliklere Göre İncelenmesi. Unpublished Doctoral Thesis. Hacettepe University Institute of Social Sciences, Ankara.

Olguntürk, E. (2005). Turizm Isşletmeleri Yönetiminde Profesyonelleşme ve Işs Tatmini İlişkisi: Ankara'daki 4 ve 5 Yıldızlı Otel Işsletmeleri Üzerine Bir Araştırma. Unpublished Master Thesis. Gazi University Institute of Social Sciences, Ankara.

Oral, S. (1994). Otel Işsletmelerinde İşin ve İşgücünün Verimliliği. (1st ed.). Izmir: Doğruluk Typography.

Oshagbemi, T. (2000a). Is Length of Service Related to the Level of Job Satisfaction?. International Journal of Social Economics, 27(3), 205-217.

Oshagbemi, T. (2000b). Satisfaction With Co-Workers' Behaviour. Employee Relations, 22(1), 88-106.

Özdamar, K. (2001). Paket Programlar ve İstatistiksel Veri Analizi (Çok Değişkenli Analizler). (4th ed.). Eskişehir: Kaan Publications.

Özgen, H., Öztürk, A. \& Yalçın, A. (2002). İnsan Kaynakları Yönetimi. (1st ed.). Adana: Nobel Bookstore.

Pelit, E. \& Güçer, E. (2007). İşletme Yöneticilerinin Çalışanlarına Karşı Davranışlarının İş Etiği Kapsamında Değerlendirilmesi Üzerine Bir Araştırma, Journal of Travel and Tourism Research, 1(2007), 32-49.

Pfeffer, J. (1994). Rekabette Üstünlüğün Sirrı: Insan. “Translated by Sinem Gül”. (1st ed.). İstanbul: Sabah Books.

Reynolds, P. (2000). Profit and Principles: Business Ethics in Hotel Management Companies in Asia. Australian Journal of Hospitality Management, 7(1), 1-14.

Sarışık, M., Akova, O. \& Çontu M. (2006). Otel Yöneticilerinin Etik Politika ve Yöntemlere Yaklaşımları Üzerine Amprik Bir Araştırma. Anatolia: An International Journal of Tourism 
and Hospitality Research, 17(1), 22-34.

Sarker, S. J., Crossman, A. \& Chinmeteepituck, P. (2003). The Relationships of Age and Lenght of Service with Job Satisfaction: An Examination of Hotel Employees in Thailand. Journal of Managerial Psychology, 18(7), 745-758.

Scandura, T. A. \& Lankau, M. J. (1997). Relationship of Gender, Family Responsibility and Flexible Work Hours to Organizational Commitment and Job Satisfaction. Journal of Organizational Behaviour, 18(4), 377-391.

Schneider, B. \& Alderfer, C. P. (1973). Three Studies of Measures of Need Satisfaction in Organizations. Administrative Science Quarterly, 489-505.

Schoorman, F. D., Mayer, R. C. \& Davis, J. H. (2007). An Integrative Model of Organizational Trust: Past, Present and Future. Academy of Management Review, 32(2), 344-354.

Schwepker, C. H. (2001). Ethical Climate's Relationship to Job Satisfaction, Organizational Commitment, and Turnover Intention in The Sales force. Journal of Business Research, 54(1), $39-52$.

Shamir, B. \& Salomon, I. (1985). Work-at-Home and The Quality of Working Life. Academy of Management Review, 10(3), 455-464.

Şimşek, B. (1999). Yöneticilerin Çalışanlara Karşı Etik Sorumlulukları. Dokuz Eylül University The Journal of Graduate School of Social Sciences, 1(3), 69-86.

Sökmen, A. \& Boylu Y. (2001). Otel İşletmeleri Yöneticileri Açısından Etik Kavramı ve Uygulamaları: Ankara 'da Amprik Bir Araştırma. Journal of Commerce \& Tourism Education Faculty Gazi University, 3(5), 31-54.

Sökmen, A. \& Tarakçıŏlu, S. (2004). Yönetici Etik Davranışların Değerlendirilmesinde Cinsiyet Faktörü: Ankara'daki Otel İşletmelerinin Sınır Departmanlarında Ampirik Bir Araştırma. 1. Balıkesir Ulusal Turizm Kongresi Bildiri Kitabı (April 15-16, 2004), 216- 250.

Spector, P. E. (1997). Job satisfaction: Application, Assessment, Causes and Consequences. (1st ed.). London: Sage Publications.

Staw, B. M. \& Ross, J. (1985). Stability in the Midst of Change: A Dispositional Approach to Job Attitudes. Journal of Applied Psychology, 70(3), 469-480.

Staw, B. M., Bell, N. F. \& Clausen, J. A. (1986). The Dispositional Approach to Job Attitudes: A Lifetime Longitudinal Test. Administrative Science Quarterly, 31(1), 56-77.

Stevens, B. \& Fleckenstein, A. (1999). Comparative Ethics: How Students and Human-resources Directors React to Real-life Situations. Cornell Hotel and Restaurant Administration Quarterly, 40(2), 69-75.

Stevens, B. (1997). Hotel Ethical Codes: A Content Analysis. International Journal of 
Hospitality Management, 16(3), 261-271.

T. R. Ministry of Culture and Tourism, (2014). Ministry Licensed Establishment Statistics 2014. Headquarters of Investments and Businesses, Ankara. [Online] Available: http://yigm.kulturturizm.gov.tr/TR,9860/turizm-belgeli-tesisler.html (January 2, 2016).

Tarakçıŏ̆u, S. (2003). Yönetici Etik Davranışlarının Değerlendirilmesinde Cinsiyet Faktörü: Ankara'daki Otel işletmelerinin Sınır Departmanlarında Ampirik Bir Araştırma. Journal of Commerce \& Tourism Education Faculty Gazi University, 5(2), 180-219.

Tarlan, D. \& Tütüncü, Ö. (2001). Konaklama İşletmelerinde Başarı Değerlemesi ve İş Doyumu Analizi. Dokuz Eylül University The Journal of Graduate School of Social Sciences, $3(2), 141-163$.

Telman, N. (1988). Endüstride Görülen İş Tatminsizliği ve Bunun Yabancılaşmayla Olan İlişkisi. (1st ed.). Istanbul: Istanbul University Institute of Social Sciences Publications.

Tepeci, M. \& Bartlett, A. B. (2002).The Hospitality Industry Culture Profile: A Measure of Individual Values, Organizational Culture and Person Organization Fit as Predictors of Job Satisfaction and Behavioral Intentions. The International Journal of Hospitality Management, 21(2), 151-170.

Togia, A., Koustelios, A. \& Tsigilis, N. (2004). Job Satisfaction Among Greek Academic Librarians. Library \& Information Science Research, 26(3), 373-383.

Tsalikis, J. \& Fritzsche, D. J. (1989). Business Ethics: A Literature Review with a Focus On Marketing Ethics. Journal of Business Ethics, 8(9), 695-743.

Turkey Ministry of Tourism. (1993). Otelcilik ve Turizm Endüstrisinde İ̧̧ücü Araştırmast. Ankara: Ministry of Tourism Publications.

Tütüncü, Ö \& Çiçek, O. (2000). İş Doyumunun Ölçülmesi: İzmir İl Sınırlarında Faaliyet Gösteren Seyahat Acentaları Üzerine Bir İnceleme. Anatolia: An International Journal of Tourism and Hospitality Research, 1(2000), 124-128.

Tütüncü, Ö. (2000). Kar Amacı Gütmeyen Yiyecek içecek İşletmelerinde İş Doyumunun Analizi. Dokuz Eylül University The Journal of Graduate School of Social Sciences, 2(3), 169-171.

Uçkun, G., Pelit, E. \& Emir, O. (2004). Otel İşgörenlerinin İş Doyumlarının Önemi ve Akçakoca'da Yerleşik Yıldızlı Otel İşletmeleri İşgörenleri Üzerinde Bir Uygulama. Journal of Commerce \& Tourism Education Faculty Gazi University, 2004(1), 39-59.

Ünlüönen, K. \& Olcay, A. (2003). Otel İşletmelerinde Çalışan İşgörenlerin Ahlak Sorumluluklarını Yerine Getirebilmesinde Eğitim Düzeyinin Önemi Üzerine Bir Araştırma. Journal of Commerce \& Tourism Education Faculty Gazi University, 2(2003), 91-112.

Ünsal, P. \& Türetgen, İ. Ö. (2005). Bir İş Doyumu Ölçeği Geliştirme Çalışması. Istanbul 
University Institute of Business Economics Management Journal, 16(51), 43-55.

Ural, A. \& Kılıç, İ. (2006).Bilimsel Araştırma Süreci ve SPSS İle Veri Analizi (SPSS 10.00 12.0 For Windows) (2nd ed.). Ankara: Detay Yayınc1lık.

Ural, T. \& Yükselen, C. (2003). Işsletme ve Pazarlama Etiği (1st ed.). Ankara: Detay Publishing.

Vitell, S. J. \& Davis, D. L. (1990). The Relationship Between Ethics and Job Satisfaction: An Empirical Investigation. Journal of Business Ethics, 9(6), 489-494.

Weeks, W. A. \& Nantel, J. (1992). Corporate Codes of Ethics and Sales Force Behaviour: A Case Study. Journal of Business Ethics, 11(10), 753-760.

Weiss, D. J., Dawis, R. V., England, G. W., \& Lofquist, L. H. (1967). Manual For The Minnesota Satisfaction Questionnaire. Minneapolis: University of Minnesota Work Adjustment Project Industrial Relations Center.

Weiss, H. M. \& Cropanzano, R. (1996). Affective Events Theory: A Theoretical Discussion Of The Structure, Causes And Consequences Of Affective Experiences At Work. In Research in Organizational Behaviour: An Annual Series of Analytical Essays and Critical Reviews. B. M. Staw, \& L. L. Cummings (Eds.), 18, 1-74. Greenwich: CT: JAI Pres. Inc.

Whitney, D. L. (1990). Ethics in the Hospitality Industry: With A Focus Hotel Managers. International Journal of Hospitality Management, 9(1), 59-68.

World Tourism Organization, (2016). Global Code of Ethics for Tourism. Ethics and Social Responsibility.

[Online] Available: http://ethics.unwto.org/en/content/global-code-ethics-tourism (January 2, 2016).

Yazıcıoğlu, İ. \& Boylu Y. (2003). Dünya Turizm Örgütünün Belirlediği Etik Kodları ve Bu Kodların Türkiye'de Uygulanmasına İlişkin Bir Araştırma. Journal of Tourism Academic, 2(2003), 41-59.

Yeh, R. (2012). Hotel General Managers' Perceptions of Business Ethics Education: Implications for Hospitality Educators, Professionals, and Students. Journal of Human $\begin{array}{lllll}\text { Resources in Hospitality } \quad \& \quad \text { Tourism, } & \text { 11(1), }\end{array}$ http://dx.doi.org/10.1080/15332845.2012.621056

Yüksel, İ. (2003). İş Stresi, İşe Bağlılık ve İş Doyumu Arasındaki İlişkinin Analizi (Teknisyenlere Yönelik Bir Araştırma). Atatürk UniversityJournal of Economics and Administrative Sciences, 17(1-2), 213-224.

Yüksel, Ö. \& Tunç, A. (2001). Turizm İşletmeleri Yöneticilerinin İş Etiğine Yaklaşımları (Ankara İli'nde Uygulamalı Bir Araştırma. Journal of Commerce \& Tourism Education Faculty Gazi University, 3(5), 57-70.

Zarvandi, N. \& Zarvandi, J. (2012). Conceptualizations of Trust in the Organization (Case 


\section{Macrothink}

Business Management and Strategy ISSN 2157-6068 2016, Vol. 7, No. 1

Study in the Education Organization of Neishabur City). Ideal Type of Management, 1(1), $37-46$.

\section{Copyright Disclaimer}

Copyright for this article is retained by the author(s), with first publication rights granted to the journal.

This is an open-access article distributed under the terms and conditions of the Creative Commons Attribution license (http://creativecommons.org/licenses/by/3.0/). 